Original research article

\title{
Personal values of caregivers in Czech social elderly care
}

\author{
Agáta Marková ${ }^{1 *}$, Miloslava Hiršová ${ }^{2}$, Lenka Komárková ${ }^{1}$ \\ ${ }^{1}$ University of Economics Prague, Faculty of Management, Department of Exact Methods, Jindřichưv Hradec, Czech Republic \\ ${ }^{2}$ University of Economics Prague, Faculty of Management, Department of Social Sciences, Jindřichův Hradec, Czech Republic
}

\begin{abstract}
The ageing population in the Czech Republic has increased the demand for the provision of health and social care for the elderly. Although social care will rapidly grow in importance, there is not enough attention paid by researchers to this area in comparison to healthcare. Since social care is a service, care staff are crucial for providing high-quality care, while staffing shortages could result in an inability to provide social care. For this reason, the personnel issue should be solved first. Strategic human resource management must not only focus on recruiting the right employees but also on retaining them. Therefore, this article aims to investigate the personal values of caregivers in Czech residential social care and analyse their impact on job satisfaction and turnover intention. The study is based on the primary data collected by our own questionnaire in nine Czech retirement homes and homes with a special regime (96 respondents). The data was analysed using standard statistical methods. The results show that caregivers prefer values based on social focus and that include both self-protection and growth needs. Currently, their job mostly satisfies their needs in these categories so they do not intend to leave in the near future. Moreover, our findings imply that job satisfaction, as a mediator of caregivers' personal values, has an impact on turnover intention. Consequently, value analysis of job applicants in social care could prevent fluctuation.
\end{abstract}

Keywords: Caregivers' Values; Job Satisfaction; Social Care HR Management; Turnover

\section{Introduction}

The growing proportion of seniors in the Czech population will have many consequences. One of these is the increasing demand for health and social care. Although research on healthcare and nursing is comprehensive (Kabene et al., 2006; Majerníková and Obročníková, 2017; Norman, 2015), social care is still neglected, despite being equally important. Therefore, more attention should be paid to research in this specific field to avoid or to mitigate the negative effects of the ageing population.

The negative effects of the growing demand for aged care could be various: insufficient capacities and poor availability, underfinancing, poor quality and especially a human resources shortage (Marková, 2016; Průša, 2017). Employees are considered to be the most precious resource for each organisation, particularly in a labour-intensive sector such as social care. Thus, staff shortages or inefficient work with human resources could represent the greatest threat to social care provision.

Unquestionably, caregivers play a crucial role in social care. Inadequate human resources, both in quantity and quality, could hinder performance achievement (Ghenţa et al., 2015) or negatively impact care quality (Eaton, 2000; Oppel et al., 2017). On the other hand, improving working conditions leading to greater job satisfaction and commitment could contrib- ute to better quality and more efficient work with human resources (Cooke and Bartram, 2015). Consequently, developing human resources management (HRM) in social care should be a priority, and this study, which focuses on caregivers' personal values, may help to address this issue.

For efficient HRM, its practice cannot favour personnel administration; more consideration must be given to strategic human resource activities (Townsend et al., 2013; Wagner et al., 2000). Strategic thinking in this area must focus on recruiting the right employees and how to retain them. With regards to the severity of this problem, many studies attempt to identify the factors influencing turnover rates and propose measures to reduce them. The development of knowledge in this area is well documented in many review studies (e.g., Cotton and Tuttle, 1986; Hancock et al., 2013; Maertz and Campion, 1998; Mobley et al., 1979; Ongori, 2007). These studies describe and investigate many factors influencing turnover rates where job satisfaction is among the most frequently mentioned.

Since the mid-1900s, job satisfaction has been a key topic of organisational behaviour science. This interest has resulted in several influential theories and job satisfaction models (Lawler and Porter, 1967; Locke and Latham, 1990; Hackman and Oldham, 1976; Herzberg, 1964; Judge and Hulin, 1993; Locke, 1976; Sabbagha et al., 2018). Although they differ in defining the content and the setting out of its impact on performance, they generally agree that job satisfaction is an effective

\footnotetext{
* Author for correspondence: Agáta Marková, University of Economics Prague, Faculty of Management, Department of Exact Methods, Jarošovská 1117/II, 37701 Jindřichův Hradec; e-mail: xmara32@vse.cz http://doi.org/10.32725/kont.2020.001

Submitted: 2019-08-10 • Accepted: 2019-11-28 • Prepublished online: 2020-01-31

KONTAKT 22/1: 68-75 • EISSN 1804-7122 • ISSN 1212-4117

(c) 2020 The Authors. Published by University of South Bohemia in České Budějovice, Faculty of Health and Social Sciences.

This is an open access article under the CC BY-NC-ND license.
} 
state of mind reflecting an individual's feelings about their job and thus influencing their intention to stay or to leave. These feelings are closely related to the degree of satisfaction of an individual's needs, which can cover a wide spectrum of factors mirroring the individual's internal and external context. It is worth noting that some studies point out that, concerning turnover intention, these personal factors do not act directly, but only through job satisfaction as a mediator (Biswas, 2009; Ferreira et al., 2017; Schreurs et al., 2014).

For the purpose of our study, we conceptualise job satisfaction as the degree of satisfying an individual's needs in their work settings. Since the energy used to satisfy one's needs is regulated not only by external context but also by the individual's value system, we decided to determine the degree of satisfaction in relation to specific values. This decision was influenced by the assumption that the value system of the people working in social care is different from those in the business sector and therefore, the sources of their job satisfaction in this area will be different (Houston, 2000).

We proceed from the Schwartz $(1992,2012)$ theory of basic values, which currently represents the most influential approach to value research (Arieli et al., 2018; Knafo et al., 2011). This theory suggests that an individual's value system reflects the basic needs of human existence, i.e. "The needs of individuals as biological organisms, requisites of coordinated social interaction, and survival and welfare needs of groups" (Schwartz, 2012, p. 4). On this basis, Schwartz derived ten values: Self-direction, Stimulation, Hedonism, Achievement, Power, Security, Conformity, Tradition, Benevolence, and Universalism. Given the needs they are based on, Schwartz grouped these values into four superior categories: Conservation, Self-enhancement, Self-transcendence, and Openness to change.

Regulation of personal or group interests, combined with self-protection associated with anxiety versus self-expansion and growth without anxiety were the main sorting aspects (four combinations). Personal focus and self-protection form the Self-enhancement category - including Achievement and Power values. Personal focus and self-expansion form the Openness to change category, in which the values of Self-direction and Stimulation are included. The interface between these two categories is Hedonism, which is partially reflected in each of them. A combination of social focus and self-protection represents the Conservation category that consists of Security, Conformity, and Tradition. The category of Self-transcendence, containing Benevolence and Universalism, is based on social focus and self-expansion.

Therefore, we will focus on the personal values of caregivers, their job satisfaction from the perspective of such values, and the link to turnover. In particular, this paper aims to answer the following three research questions:

- RQ1: Which personal values do caregivers prefer?

- RQ2: Which of these values are associated with job satisfaction?

- RQ3: For which values does job satisfaction act as a mediator in influencing turnover intention?

\section{Materials and methods}

The study is based on primary data that was collected by a questionnaire survey in 2018. The survey focused on residential care for the elderly and was conducted in nine social care organisations. Although this is not a large number, there was an attempt to compensate for this by the maximum possible diversity. The organisations consist of five retirement homes (RH), one home with a special regime (HwsR), and three organisations providing both these social care services (Unspecified). They are situated in four different $\mathrm{Czech}$ regions (Prague -4 , Central Bohemia - 2, Vysočina - 2, South Bohemia - 1) and were of different sizes. In addition, six of them were public (state-subsidised organisations, non-profit) and three were private (limited companies, for-profit). The research group were caregivers, excluding nurses, social workers, managers and maintenance staff. The final sample comprised 96 respondents.

Table 1 summarises the characteristics of caregivers in the sample and their differentiation by the type of social care services. Most of the caregivers were women (89.6\%); the average age was 41.3 ; the most frequent educational level was secondary; the average length of praxis was 5.8 years. These characteristics are very similar to those which were investigated in other countries as the typical characteristics of caregivers (Atkinson and Lucas, 2013; Smith and Baughman, 2007; Wong, 2008).

Table 1. Characteristics of caregivers in the sample

\begin{tabular}{|c|c|c|c|c|}
\hline Characteristics & Sample & $\mathrm{RH}$ & HwsR & Unspecified \\
\hline Number & 96 & $68(70.8 \%)$ & $12(12.5 \%)$ & $16(16.7 \%)$ \\
\hline \multicolumn{5}{|l|}{ Gender } \\
\hline Female & $86(89.6 \%)$ & $60(88.2 \%)$ & $11(91.7 \%)$ & $15(93.8 \%)$ \\
\hline Male & $5(5.2 \%)$ & $3(4.4 \%)$ & $1(8.3 \%)$ & $1(6.2 \%)$ \\
\hline N/A & $5(5.2 \%)$ & $5(7.4 \%)$ & 0 & 0 \\
\hline Age & 41.3 & 41.4 & 38.9 & 42.8 \\
\hline \multicolumn{5}{|l|}{ Highest education level } \\
\hline Primary & $5(5.2 \%)$ & $5(7.4 \%)$ & 0 & 0 \\
\hline Secondary & 75 (78.1\%) & $50(73.5 \%)$ & $9(75.0 \%)$ & $16(100 \%)$ \\
\hline Tertiary technical & $6(6.3 \%)$ & $5(7.4 \%)$ & $1(8.3 \%)$ & 0 \\
\hline Tertiary (University) & $4(4.2 \%)$ & $2(2.9 \%)$ & $2(16.7 \%)$ & 0 \\
\hline N/A & $6(6.3 \%)$ & $6(8.8 \%)$ & 0 & 0 \\
\hline Average length of employment & 5.8 & 6.0 & 5.8 & 5.4 \\
\hline
\end{tabular}


The questionnaire consisted of three parts. The first part comprised seven questions investigating the basic characteristics of the caregiver in terms of gender, education and age presented in Table 1. The second part was focused on personal values and was derived from the Schwartz Value Survey - SVS (Schwartz, 1992). We used the short version of the SVS questionnaire, where each of the ten values is represented by only one item (Lindeman and Verkasalo, 2005). Instead of a ninepoint scale, a seven-point scale was used (1 - totally unimportant values, 7 - totally important values) for this evaluation. According to Betz (1996), the use of five- to seven-point scales in questionnaires is optimal for completion.

Finally, the third part consisted of eight statements expressing job satisfaction (JS), which can also be referred to as needs satisfaction in a work setting, in relation to personal vs social focus and self-protection vs self-enhancement dichotomy, as mentioned above. These concerned four combinations: JS1 (personal focus and self-protection); JS2 (personal focus and self-expansion); JS3 (social focus and self-protection); and JS4 (social focus and self-expansion); each was assessed by two items. Additionally, there were two more statements investigating the caregivers' intention to leave their job in the future. The caregivers evaluated their agreement with these statements on the seven-point scale (1 - totally disagree, 7 totally agree).
The data was analysed using standard statistical methods, especially descriptive statistics, a paired $t$-test, and multiple linear regression. All the results were interpreted at a 5\% significance level. To distinguish between the results concerning value preferences and satisfaction in the associated areas, we use the term 'category' for the first case and the term 'dimension' for the second.

\section{Results and discussion}

RQ1 investigated the personal values of caregivers in Czech residential social care. The respondents identified Benevolence, Conformity, and Security as the most important values (Table 2). There was no statistically significant difference between the two types of considered residential care $\mathrm{RH}$ and HwsR ( $p$-value 0.49). By observing the particular characteristics of the highest rated values (in italics in Table 2), we can see that they correspond with such forms of behaviour as helpfulness, responsibility, politeness, honouring parents and elders, family security and a sense of belonging, which are in accordance with the nature of the respondents' work.

\section{Table 2. Personal values - average evaluation}

\begin{tabular}{|c|c|c|c|}
\hline Values & Total & $\mathrm{RH}$ & HwsR \\
\hline Power (social power, authority, wealth) & 3.2 & 3.1 & 3.6 \\
\hline Achievement (successful, ambitious, influential) & 4.7 & 4.6 & 4.9 \\
\hline Hedonism (pleasure, enjoy life) & 4.8 & 4.5 & 5.2 \\
\hline Stimulation (an exciting and varied life) & 4.6 & 4.5 & 4.3 \\
\hline Self-direction (freedom, creativity, independence) & 5.5 & 5.4 & 5.6 \\
\hline Tradition (respect for tradition, devout, accepting life destiny, humble) & 5.6 & 5.7 & 4.8 \\
\hline Conformity (obedient, self-discipline, politeness, honouring parents and elders) & 6.1 & 6.0 & 5.8 \\
\hline Security (national security, family security, social order, sense of belonging) & 6.0 & 6.1 & 5.3 \\
\hline Universalism (equality, unity with nature, wisdom, social justice, peaceful world) & 5.6 & 5.7 & 4.8 \\
\hline Benevolence (helpful, responsible, honest, loyal, forgiving) & 6.2 & 6.3 & 6.3 \\
\hline
\end{tabular}

Moreover, the results correspond with Schwartz's (2012) findings that Conformity and Security maintain the existing social arrangements that give life certainty, and that Benevolence is one of the values generally preferred across national cultures. Summarising these results, we can conclude that caregivers prefer those categories of values that are based on social focus and include both self-protection and growth needs (Conservation and Self-transcendence, respectively). In terms of using value preferences in personnel work, it is important to point out a higher level of Benevolence and Universalism at a lower Power level. According to Tartakovsky (2015), these results form a substantial part of a value pattern associated with a lower likelihood of burnout. For better understanding, the results are also depicted in Fig. 1.

First, the average scores for each of the job satisfaction dimensions are shown in Table 3. Before interpreting these results, it should be borne in mind that the job satisfaction assessment was based on the nature of the superior value cat- egories, thus using a more general measure than would correspond to the attributes of ten basic values. The paired $t$-test again did not prove any difference between $\mathrm{RH}$ and HwsR ( $p$-value 0.3). Thus, further parts will not distinguish them.

The highest score (5.6) was achieved by JS3 (Table 3). Compared with Table 2, it is evident that the highest level of caregivers' job satisfaction (JS3) corresponds with their value preferences (Benevolence, Conformity, Security). JS3 is based on conditions associated with personal values, such as Security, Conformity, and Tradition (Fig. 1). This set of values forms the category of Conservation, which is an orientation on social needs and self-protection. We can assume that in this respect, the nature of caregiving can indeed provide an appropriate environment for satisfying these needs. In addition, the preference of the Conservation category usually leads to non-conflicting behaviour and respect for supervisors' authority in the work environment (Anjum et al., 2014). 


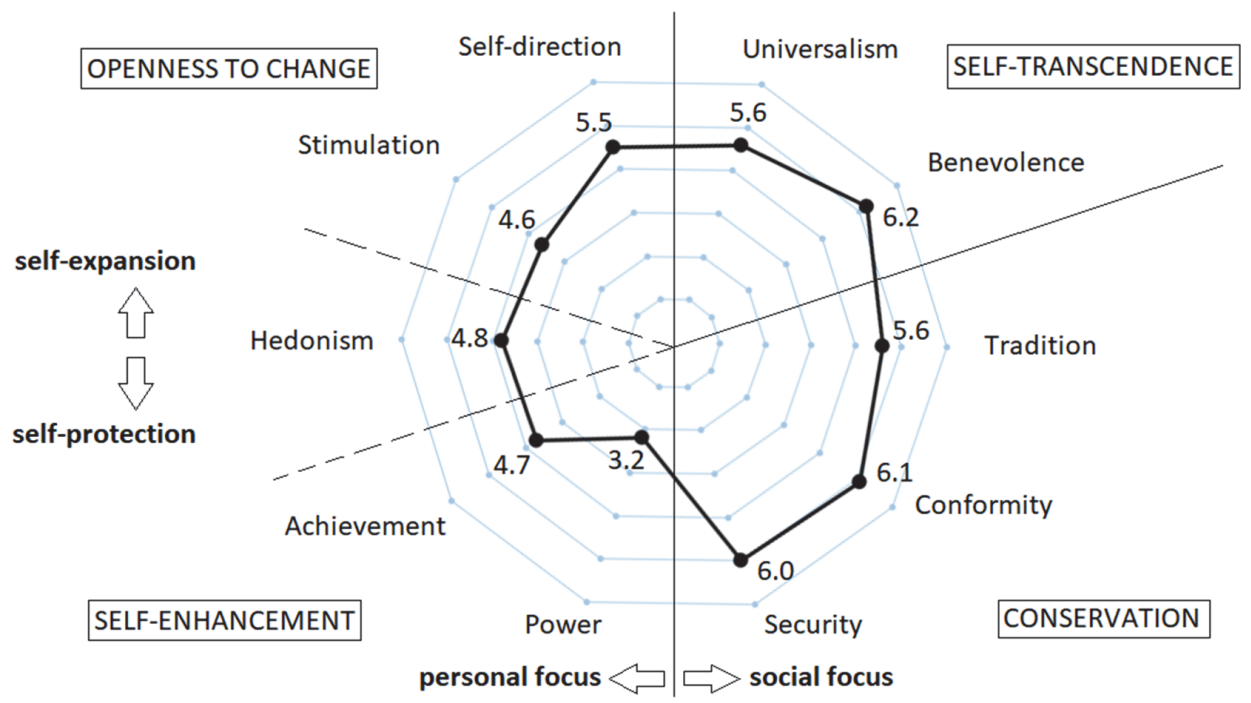

Fig. 1. Spider graph summarising personal value evaluation, values categories, job satisfaction dimensions

Table 3. Evaluation of job satisfaction statements

\begin{tabular}{lccc} 
& Total & RH & HwsR \\
\hline JS1 (personal focus and self-protection) & 1.6 & 1.7 & 1.5 \\
JS2 (personal focus and self-expansion) & 5.0 & 5.1 & 4.5 \\
JS3 (social focus and self-protection) & 5.6 & 5.7 & 5.0 \\
JS4 (social focus and self-expansion) & 5.2 & 5.2 & 4.8 \\
\hline
\end{tabular}

In the next step, the relations between personal values and job satisfaction dimensions were analysed. The results of multiple linear regression (Table 4) shows that there are several statistically significant relations. Once again, it should be noted that the dimensions of job satisfaction were measured only in relation to the second-order categories as a whole, not to individual values. Therefore, the results of the individual values constituting the relevant category may not appear to be significant. Based on our results, the previously mentioned JS3 is associated with the preference of the value of Power ( $p$-value 0.02). Since this superior category includes the values of $\mathrm{Se}$ curity, Tradition, and Conformity, it is obvious that it is closely related to the need for order and rules. Thus, Power can serve as an important tool to enforce and preserve this order.

Similar outcomes concerning the importance of this value category for job satisfaction can be found in Tamayo (2001) or Porto and Tamayo (2012), although their research was aimed at specific features of job satisfaction. On the contrary, Camfield et al. (2018) did not confirm any significant relationship between job satisfaction and Conservation values. However, their research sample was not homogeneous in the type of the respondents' profession. Thus, we can assume that the relation between Conservation and job satisfaction is sensitive to the nature of the job. However, in the field of personnel work, it should be noted that this category is associated with a reluctance to change and the low proactivity of employees (Parker et al., 2010).

Table 4. Relation between job satisfaction and personal values - Linear regression parameters estimation

\begin{tabular}{|c|c|c|c|c|c|c|c|c|}
\hline \multirow[b]{2}{*}{ Independent variables } & \multicolumn{2}{|c|}{ JS1 } & \multicolumn{2}{|c|}{ JS2 } & \multicolumn{2}{|c|}{ JS3 } & \multicolumn{2}{|c|}{ JS4 } \\
\hline & $\beta$ & $p$-value & $\beta$ & $p$-value & $\beta$ & $p$-value & $\beta$ & $p$-value \\
\hline Power & -0.08 & 0.37 & -0.04 & 0.70 & 0.24 & $0.02^{\mathrm{b}}$ & 0.05 & 0.59 \\
\hline Achievement & 0.10 & 0.34 & -0.08 & 0.47 & -0.11 & 0.36 & -0.21 & $0.07^{\mathrm{a}}$ \\
\hline Hedonism & -0.20 & $0.04^{\mathrm{b}}$ & 0.05 & 0.63 & -0.20 & $0.08^{\mathrm{a}}$ & -0.15 & 0.16 \\
\hline Stimulation & -0.08 & 0.39 & -0.06 & 0.60 & 0.13 & 0.25 & 0.22 & $0.04^{\mathrm{b}}$ \\
\hline Self-direction & 0.09 & 0.38 & 0.12 & 0.30 & -0.01 & 0.96 & 0.00 & 0.98 \\
\hline Tradition & -0.05 & 0.70 & 0.42 & $<0.01^{c}$ & -0.06 & 0.67 & -0.20 & 0.15 \\
\hline Conformity & -0.03 & 0.83 & -0.31 & $0.05^{\mathrm{b}}$ & 0.09 & 0.58 & 0.07 & 0.66 \\
\hline Security & -0.02 & 0.88 & 0.01 & 0.93 & 0.01 & 0.94 & 0.17 & 0.28 \\
\hline Universalism & -0.07 & 0.47 & -0.15 & 0.16 & 0.06 & 0.62 & 0.08 & 0.47 \\
\hline Benevolence & -0.15 & 0.21 & 0.06 & 0.65 & 0.08 & 0.57 & 0.06 & 0.63 \\
\hline
\end{tabular}


In this context, it is worth noting that the dimension of Self-enhancement (JS1), which differs from Conservation (JS3) in its personal focus, has received the lowest rating (1.6). Thus, in this case, it is necessary to mention dissatisfaction. Although this outcome is also consistent with a low ranking in personal value preferences (Table 2, Fig. 1), the significantly low score in this dimension of job satisfaction should draw attention to possible sources of problems that may be related to the nature of this job or profession. This threat is also underlined by the statistically significant negative impact of Hedonism on this dimension (see the sign of the Hedonism parameter estimate for the JS1 response in Table 4). We can assume that the source of dissatisfaction in JS1 (personal focus and self-protection) may be caused by frustration in the area of basic personal existential needs and interests and by conditions that provide little enjoyment and pleasure in life.

As to the degree of satisfaction with job conditions, those allowing Self-transcendence (JS4: 5.2) closely follow the Conservation dimension (JS3: 5.6). This superior category is based on social needs and needs for self-expansion and growth. It is usually associated with the need to transcend one's own interests and be responsible to the wider social environment. Again, we can assume that such values correspond to the nature of caregiving. Satisfaction in this dimension is significantly positively influenced by the Stimulation value (parameter estimate is 0.22).

Stimulation also reflects needs associated with expansion and growth, but with a focus on personal interests. The observed relationship may point to the need to link personal interests and needs with those of the social in-group, and thus, may be closely related to motivation for caregiving. For HRM, employees should have this value orientation, which is in line with their work conditions.

Satisfaction with job conditions that enables Openness to change (JS2) occupied the third position - although its distance from previous dimensions (JS3 and JS4) is very small. This means that respondents perceive adequate space in their work to meet their personal growth needs. However, it is surprising that satisfaction in this dimension is positively related to the Tradition value (even at $1 \%$ significance level).

Tradition is generally considered to be the opposite of creativity and Openness to change. When compared with Conformity, which belongs to the same superior category as Tradition, we can find the negative relationship of the Conformity value to satisfaction in this area. An explanation can be found in Schwartz's (1992) description of these values, where Tradition is explained as a more abstract concept related to cultural practices, while Conformity leads individuals to behave in accordance with the group's expectations and not to disrupt the functioning of the group as a whole.

Therefore, we can assume that satisfaction with opportunities for change prevails and can be supported by the traditional concept of the profession and the traditional expectations of the wider social environment. However, in the context of a narrower working group, the degree of Conformity can create an atmosphere where social support in the pursuit of change or growth is lowered.

Finally, RQ3 analysed a mediation role of job satisfaction in relation to personal values and turnover intention. An average turnover intention score of 2.9 indicates that the caregivers do not seriously plan to leave their job in the near future. While Table 4 summarises the relationship between values and job satisfaction, the impact of values and job satisfaction on turnover intention should be analysed to assess job satisfaction as a mediator (Hendl, 2010; Heyes, 2013).
As seen in Table 5, there is the only one value - Power - that directly impacts the intention to leave the job. This means that those people for whom the needs of personal interests and self-protection associated with social power, authority, and wealth are important, the turnover tendencies could be lower. This is a finding that requires further attention. It is known that some people with a high need for power seek employment where they can satisfy that need. Jobs that provide a legitimate source of power over others, which includes caregiving, attract such people and give them the opportunity to abuse it. Nevertheless, compared with the low ratings in Power preferences (Table 2) this danger does not appear to be high.

\begin{tabular}{lcc}
$\begin{array}{l}\text { Table 5. How personal values and job satisfaction influence } \\
\text { turnover intention - Linear regression parameters } \\
\text { estimation }\end{array}$ & $\beta$ & $p$-value \\
\hline Independent variables & -0.27 & $0.05^{\mathrm{a}}$ \\
\hline Power & -0.02 & 0.92 \\
Achievement & 0.08 & 0.60 \\
Hedonism & -0.16 & 0.27 \\
Stimulation & -0.16 & 0.33 \\
Self-direction & -0.26 & 0.21 \\
Tradition & 0.23 & 0.31 \\
Conformity & -0.12 & 0.55 \\
Security & 0.12 & 0.42 \\
Universalism & 0.01 & 0.97 \\
Benevolence & -0.09 & 0.65 \\
JS1 & -0.74 & $<0.01^{\mathrm{c}}$ \\
JS2 & -0.26 & 0.12 \\
JS3 & 0.34 & $0.07^{\mathrm{a}}$ \\
JS4 & &
\end{tabular}

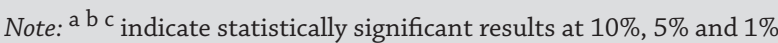
sig. level.

The impact of other values on turnover intention is indirect, with job satisfaction behaving as a mediator. Namely, the dimension of Openness to change (JS2) featuring the satisfaction of needs for personal growth and expansion, where the impact of the values Tradition and Conformity plays a key role. This corresponds to the findings presented in Table 4, where this relationship was also found. It should be noted at this point that the research design does not allow for deeper interpretation and we can only assume, with regards to the character of the questionnaire items, that Tradition and Conformity reflect the nature of the social atmosphere in the working group. When this atmosphere leads to dissatisfaction with opportunities for personal growth and change, it may be the source of turnover intention.

A similar relationship, but only at the $10 \%$ significance level, was found between the Self-transcendence dimension (JS4) and the Stimulation value. Again, this corresponds to the findings presented in Table 4 . In practice, this means that if respondents are frustrated in these aspects of their personal growth opportunities, it calls for dissatisfaction in the Self-transcendence dimension, generally associated with life meaningfulness and unity with the universe. Frustration in these basic needs associated in their core with the survival and welfare of social groups may then lead to turnover intention. 
In light of these findings, in accordance with the theory of work adjustment (Dawis and Lofquist, 1984), we can conclude that value preferences and the degree of satisfaction of the needs they are based on have an important role in turnover intention. Thus, HRM practice needs to pay close attention to the person-organization fit in this respect (De Clercq et al., 2008).

\section{Limitations}

The study had some limitations. Despite the effort to maximise the number of respondents and ensure the diversity of the social care organisations, the sample is limited in this respect and should be extended in further research. Second, the study is focused only on residential social care. Caregivers in both field or outpatient social services also play an important role in social care provision and their personal value profile has not been investigated. Further, with respect to the sample size, the gender or legal form (non-profit/for-profit) differences cannot be analysed. Finally, the shortened Schwartz questionnaire was used. Although its validity and reliability are good, compared to the original version (Lindeman and Verkasalo, 2005), the interpretation of results based on the full range of questionnaire items could be deeper. Similarly, in our study, job satisfaction was related to value superior categories instead of particular values. Therefore, further research could focus on a deeper level of analysis.

\section{Conclusions}

Czech society is ageing, which influences health and social care demand. While healthcare research is comprehensive (from medical issues to financing, management, etc.), social care is still a neglected research area. Since caring is a labour-intensive occupation, human resources are a key aspect of social care provision in the appropriate quality and quantity. Thus, recruiting and retaining the right employees should be the priority of human resource management in this specific field.

Based on the findings of the previous research, our study aimed to look into the value preferences of caregivers in Czech social residential care for the elderly and investigate their impact on job satisfaction and potentially on turnover intention. Our findings show that caregivers prefer such values as Benevolence, Conformity, and Security. These values are based on social focus, and it could be assumed that they correspond with the nature of care work. This assumption was supported by the following results, which show that caring mostly satisfies caregivers' needs related to social focus and self-protection (JS3). Higher levels of satisfaction in dimensions that are assumed to be linked to the characteristics of caregiving may also be associated with low turnover intention. This relationship between the variables under examination is also supported by the findings that job satisfaction actually acts as a mediator between individual value preferences and turnover intention.

The theoretical contribution of our study lies in analysing the impact of the values on turnover through job satisfaction as a mediator in the specific field of social care, which, as far as we know, has not been explored in-depth. In contrast to the other studies that examine work values or use other measuring methods of value preferences than the Schwarz questionnaire, our study shows that the use of the Schwartz value model can be beneficial in social welfare practice, even with regard to simple data collection and evaluation. Our results imply that job satisfaction is closely related to the conditions or the nature of the work. Therefore, such an analysis should be included in $\mathrm{HRM}$, and its results could contribute to better work with human resources.

Although the current employment situation does not really allow social care providers to choose employees and order their qualities, especially in the social care sector (which is not highly prestigious), a value analysis of job applicants could support finding the right employees and lower turnover intention in the future. Value-based recruitment could prevent the recruitment of people who are not only dissatisfied in their job, but also provide poor care or even put clients at risk. Personal values cannot be taught in education courses; nevertheless, desirable personal values should be communicated to attract such people in the field. In the next step, knowing the employees' value profile should contribute to better management, motivation and development. However, advanced research on this topic is necessary for value-based recruitment and management in social care.

\section{Conflict of interests}

The authors are not aware of any conflict of interests to disclose.

\section{Acknowledgement}

The article was supported by the research grant: $C z e c h$ Science Foundation GAČR [nr. 18-01159S].

\section{Osobní hodnoty pečovatelů v české sociální péči o seniory}

\section{Souhrn}

Stárnutí populace má za následek zvyšující se poptávku po zdravotní a sociální péči o seniory. Ačkoli význam sociální péče stále narůstá, ve srovnání se zdravotní péčí není výzkumu v této oblasti věnována dostatečná pozornost. Jelikož sociální péče je služba, pro poskytování kvalitní péče je stěžejní personál, jehož nedostatek by vedl k ohrožení zajištění péče. $Z$ tohoto důvodu by personální otázce měla být věnována prioritní pozornost. Strategický HR management by se měl zaměřit nejen na nábor správných lidí, ale také na jejich udržení. Tento článek má za cíl zjistit osobní hodnoty pečovatelů v české pobytové sociální péči a analyzovat jejich vliv na pracovní spokojenost a fluktuaci. Studie vychází z primárních dat sesbíraných prostřednictvím vlastního dotazníku v devíti českých domovech pro seniory a domovech se zvláštním režimem (96 respondentů). Data byla analyzována standardními statistickými metodami. Výsledky ukazují, že pečovatelé preferují hodnoty založené na sociálním zaměření zahrnující jak potřeby sebeochrany, tak růstu. V současné době jejich práce uspokojuje jejich potřeby v těchto kategoriích, a proto neuvažují o odchodu ze zaměstnání. Naše výsledky naznačují, že pracovní spokojenost jako mediátor osobních hodnot pečovatelů ovlivňuje tendenci k odchodu. Proto by analýza osobních hodnot uchazečů o práci v sociální péči mohla přispět k prevenci jejich fluktuace.

Klíčová slova: fluktuace; hodnoty pečovatelů; HR management v sociální péči; pracovní spokojenost 


\section{References}

1. Anjum MA, Karim J, Bibi Z (2014). Relationship of values and conflict management styles. IBA Business Review 9(1): 92-103.

2. Arieli S, Sagiv L, Roccas S (2018). Values at work: The impact of personal values in organisations. Appl Psychol. DOI: 10.1111/ apps.12181.

3. Atkinson C, Lucas R (2013). Worker responses to HR practice in adult social care in England. Hum Resour Manag J 23(3): 296-312. DOI: 10.1111/j.1748-8583.2012.00203.x.

4. Betz NE (1996). Test construction. In: Leong FTL, Austin JT (Eds). The psychology research handbook: A guide for graduate students and research assistants. US: Sage Publications, Inc, pp. 239-250.

5. Biswas $S$ (2009). Job satisfaction and job involvement as mediators of the relationship between psychological climate and turnover intention. SAJM 16(1): 27-43.

6. Camfield CER, von Borell AD, Rodrigues RG (2018). An analysis of the relationship between personal values and satisfaction with work. Brazilian Journal of Management/ Revista de Administração da UFSM 11(5): 1240-1256. DOI: 10.5902/1983465916992.

7. Cooke FL, Bartram T (2015). Guest editors' introduction: human resource management in health care and elderly care: current challenges and toward a research agenda. Hum Resour Manag 54(5): 711-735. DOI: 10.1002/hrm.21742.

8. Cotton JL, Tuttle JM (1986). Employee turnover: a metaanalysis and review with implications for research. Academy of Management Review 11(1): 55-70. DOI: 10.5465/ AMR.1986.4282625.

9. Dawis RV, Lofquist LH (1984). A psychological theory of work adjustment: An individual-differences model and its applications. Minneapolis: University of Minnesota Press.

10. De Clercq S, Fontaine JR, Anseel F (2008). In search of a comprehensive value model for assessing supplementary person-organization fit. J Psychol 142(3): 277-302. DOI: 10.3200/JRLP.142.3.277-302.

11. Eaton SC (2000). Beyond 'unloving care': Linking human resource management and patient care quality in nursing homes. The Int J Hum Resour Man 11(3): 591-616. DOI: $10.1080 / 095851900339774$.

12. Ferreira AI, Martinez LF, Lamelas JP, Rodrigues RI (2017) Mediation of job embeddedness and satisfaction in the relationship between task characteristics and turnover: A multilevel study in Portuguese hotels. Int J Contemp Hosp Manag 29(1): 248-267. DOI: 10.1108/IJCHM-03-2015-0126.

13. Ghenţa M, Matei A, Mladen L (2015). Performance measurement in social care services for older people. Romanian Journal for Multidimensional Education / Revista Romaneasca pentru Educatie Multidimensionala 7(2): 97-109. DOI: $10.18662 / \mathrm{rrem} / 2015.0702 .09$.

14. Hackman JR, Oldham GR (1976). Motivation through the design of work: test of a theory. Organ Behav Hum Perform 16(2): 250-279. DOI: 10.1016/0030-5073(76)90016-7.

15. Hancock JI, Allen DG, Bosco FA, McDaniel KR, Pierce, CA (2013). Meta-analytic review of employee turnover as a predictor of firm performance. J Manag 39(3): 573-603. DOI: $10.1177 / 0149206311424943$.

16. Hendl J (2010). Analýza působení mediátorových a moderátorových proměnných. Informační bulletin České statistické společnosti 21(1): 1-15.

17. Herzberg F (1964). The motivation-hygiene concept and problems of manpower. Personnel Administration (27): 3-7.

18. Heyes AF (2013). Introduction to mediation, moderation, and conditional process analysis: a regression-based approach. New York: The Guilford Press.

19. Houston DJ (2000). Public-service motivation: a multivariate test. JPART 10(4): 713-727. DOI: 10.1093/oxfordjournals. jpart.a024288.
20. Judge, TA, Hulin CL (1993). Job satisfaction as a reflection of disposition: A multiple source causal analysis. Organ Behav Hum Dec 56(3): 388-421. DOI: 10.1006/obhd.1993.1061.

21. Kabene SM, Orchard C, Howard JM, Soriano MA, Leduc R (2006). The importance of human resources management in health care: A global context. Hum Resour Health 4(1): 20. DOI: 10.1186/1478-4491-4-20.

22. Knafo A, Roccas S, Sagiv L (2011). The value of values in cross-cultural research: A special issue in honor of Shalom Schwartz. J Cross Cultur Psychol 42(2): 178-185. DOI: 10.1177/0022022110396863.

23. Lawler EE III., Porter LW (1967). The effect of performance on job satisfaction. Industrial Relations: Journal of Economy and Society 7(1): 20-28. DOI: 10.1111/j.1468-232X.1967. tb01060.x.

24. Lindeman $M$, Verkasalo $M$ (2005). Measuring values with the Short Schwartz's value survey. J Pers Assess 85(2): 170-178. DOI: 10.1207/s15327752jpa8502_09.

25. Locke EA (1976). The nature and causes of job satisfaction. In: Dunnette MD (Ed.). Handbook of industrial and organizational psychology, Vol. 1: 1297-1343.

26. Locke EA, Latham GP (1990). A theory of goal setting and task performance. Englewood Cliffs, N. J.: Prentice-Hall.

27. Maertz CP, Jr., Campion MA (1998). 25 years of voluntary turnover research: A review and critique. International Review of Industrial and Organizational Psychology 13: 49-81.

28. Majerníková L', Obročníková A (2017). Personality predictors and their impact on coping with burnout among students preparing for the nursing and midwifery profession. Kontakt 19(2): 93-98. DOI: 10.1016/j.kontakt.2017.02.002.

29. Marková A (2016). Stárnutí populace ČR jako problém budoucnosti a otázka udržitelnosti sociální péče o seniory. Jindřichův Hradec: Vysoká škola ekonomická v Praze.

30. Mobley WH, Griffeth RW, Hand HH, Meglino BM (1979). Review and conceptual analysis of the employee turnover process. Psychol Bull 86(3): 493-522. DOI: 10.1037/00332909.86.3.493.

31. Norman K (2015). How mentors can influence the values, behaviours and attitudes of nursing staff through positive professional socialisation. Nurs Manag (Harrow) 22(8): 33-38. DOI: $10.7748 / \mathrm{nm} \cdot 22.8 .33 . \mathrm{s} 28$.

32. Ongori $\mathrm{H}$ (2007). A review of the literature on employee turnover. Afr J Bus Manag 1(3): 49-54.

33. Oppel EM, Winter V, Schreyögg J (2017). Evaluating the link between human resource management decisions and patient satisfaction with quality of care. Health Care Manage Rev 42(1): 53-64. DOI: 10.1097/HMR.0000000000000087.

34. Parker SK, Bindl UK, Strauss K (2010). Making things happen: A model of proactive motivation. J Manag 36(4): 827-856. DOI: 10.1177/0149206310363732.

35. Porto JB, Tamayo Á (2012). Estrutura dos Valores Pessoais: A Relação entre Valores Gerais e Laborais. Psicologia: Teoria e Pesquisa 23(1): 63-70. DOI: 10.1590/S010237722007000100008.

36. Průša L (2017). Důsledky změn věkové struktury obyvatelstva na vývoj nákladů na poskytování zdravotní péče. Demografie 59(1): 33-48.

37. Sabbagha MFS, Martins N, Ledimo O (2018). Conceptual model of employee motivation and job satisfaction for staff retention practices in foreign exchange banking context. In: ICMLG 2018 6th International Conference on Management Leadership and Governance (p. 309). Bankok University Thailand.

38. Schreurs B, van Emmerik IH, van den Broeck A, Guenter H (2014). Work values and work engagement within teams: the mediating role of need satisfaction. In: Marcus DK (Ed.). Group Dynamics: Theory, Research, and Practice. Advance online publication. DOI: $10.1037 /$ gdn0000009.

39. Schwartz SH (1992). Universals in the content and structure of values: Theoretical advances and empirical tests in 20 countries. Adv Exp Soc Psychol 25: 1-65. DOI: 10.1016/S00652601(08)60281-6. 
40. Schwartz SH (2012). An overview of the Schwartz theory of basic values. Online Readings in Psychology and Culture 2(1): article 11. DOI: 10.9707/2307-0919.1116.

41. Smith K, Baughman R (2007). Caring for America's aging population: a profile of the direct-care workforce. Monthly Labor Rev 130: 20-26.

42. Tamayo Á (2001). Prioridades axiológicas, atividade física e estresse ocupacional. Rev Adm Contemp 5(3): 127-147. DOI: 10.1590/S1415-65552001000300007.

43. Tartakovsky E (2015). Personal value preferences and burnout of social workers. J Soc Work 16(6): 657-673. DOI: 10.1177/1468017315589872.
44. Townsend K, Lawrence SA, Wilkinson A (2013). The role of hospitals' HRM in shaping clinical performance: a holistic approach. Int J Hum Res Manag 24(16): 3062-3085. DOI: 10.1080/09585192.2013.775028.

45. Wagner R, Hlavacka S, Bucharova L (2000). Hospital human resource planning in Slovakia. J Manag Med 14(5-6): 383-405. DOI: 10.1108/02689230010363007.

46. Wong L (2008). The third sector and residential care for the elderly in china's transitional welfare economy. AJPA 67(1): 89-96. DOI: 10.1111/j.1467-8500.2007.00571.x. 